\title{
Effects of a change in the daily time of access to hay on the rate of eating and feed intake of dairy cows
}

\author{
Shozo Suzuki, Yozo Shinde and Hisashi Hidari \\ (Obihiro Zootechnical University, Hokkaido, Japan) \\ (Received for Publication on March 10, 1970)
}

\begin{abstract}
Altering the length of daily feeding time induces metabolic and behavioural adaptations in animals. When the daily time of access to feed was limited the rate of eating increased to prevent a reduction in the feed intake of cows $^{2}$. Similar results have been reported in rats ${ }^{6}$ ) and in chickens ${ }^{4)}$. Lepкovsky et al.$^{9}$ have reported that chickens trained to eat their daily food in two hours adapted at the crop, enabling it to hold more food. Furthermore, changes have been reported in intermediary metabolism such as thyroid activity and body fat following the restriction of the length of daily feeding time ${ }^{11}$.

In the practical feeding of farm animals it has been generally suggested that sudden changes of feeding system are undesirable; there are, however, many points about such changes which are not clear. In order to provide a better understanding of behavioural adjustments, the time of eating, the feed intake and the rate of eating were observed successively on dairy cows in which daily time of access to feed was changed abruptly from, for example, $24 \mathrm{hr}$ to $4 \mathrm{hr}$ and vice versa.
\end{abstract}

\section{Experimental}

Cows and feeds:

Sixteen non-lactating Holstein cows, 3-10 years old and $512-708 \mathrm{~kg}$ live weight, were fed on mixed hay, predominantly Timothy, as a sole feed. They were tied in a cowshed during the experimental period. Salt licks and water were accessible at all times. The mean chemical composition of the hay is given in Table 1 .

Table 1. Chemical composition of hay fed to each group (\%)

\begin{tabular}{ccccccc}
\hline \hline Group & Moisture & Crude protein & Crude fat & N.F.E. & Crude fibre & Crude ash \\
\hline I & 11.8 & 9.5 & 2.9 & 40.1 & 26.9 & 8.8 \\
II & 12.9 & 8.5 & 2.3 & 44.2 & 25.3 & 6.8 \\
III & 11.8 & 9.5 & 2.9 & 40.1 & 26.9 & 8.8 \\
IV & 12.6 & 6.3 & 2.2 & 45.3 & 27.4 & 6.2 \\
\hline
\end{tabular}

Recording:

Hanging mangers, strain amplifiers and a recorder described in the previous report ${ }^{5 i}$ were used for recording the eating behaviour. The speed of the charts was $150 \mathrm{~mm}$ per hr and records were made all the time cows had access to the feed.

Experimental plan:

The animals were divided into four groups, each of four cows, and the time cows had access 


\section{SUZUKI - SHINDE - HIDARI}

to feed daily was changed for Groups I, II, III and IV from 24-hr to one meal of 4-hr, vice versa, from $24-\mathrm{hr}$ to two meals of $2-\mathrm{hr}$ and vice versa, respectively. In $24-\mathrm{hr}$ and a $4-\mathrm{hr}$ feeding hay was offered at $08.00 \mathrm{~h}$, while in $2 \times 2-\mathrm{hr}$ feeding offered in two meals at $06.00 \mathrm{~h}$ and $16.00 \mathrm{~h}$. The amount of hay offered was adjusted so that the unsaten portion was about $10 \%$ of the amount offered.

\section{Results}

Differences due to daily feeding time:

Mean daily time spent eating, mean daily intake and mean rate of eating were calculated from the values for the last 5 days of each treatment and are given in Table 2 .

Table 2. Daily time spent eating, daily hay intake and mean rate of eating in the four groups (Mean with S.E.)*

\begin{tabular}{|c|c|c|c|c|c|c|}
\hline & \multirow{2}{*}{ Group } & \multicolumn{2}{|c|}{ Daily feeding time } & \multirow{2}{*}{ Group } & \multicolumn{2}{|c|}{ Daily feeding time } \\
\hline & & $24-\mathrm{hr}$ & $4-\mathrm{hr}$ & & $24-\mathrm{hr}$ & $2 \times 2-\mathrm{hr}$ \\
\hline \multirow{2}{*}{$\begin{array}{c}\text { Time spent eating } \\
(\mathrm{min} / \text { day) }\end{array}$} & I & $386 \pm 18.7$ & $226 \pm 6.2$ & III & $494 \pm 18.0$ & $240 \pm 0.0$ \\
\hline & II & $419 \pm 32.1$ & $204 \pm 6.5$ & IV & $440 \pm 20.1$ & $238 \pm 1.0$ \\
\hline \multirow{2}{*}{$\underset{(\mathrm{kg})}{\text { Daily hay intake }}$} & I & $11.1 \pm 1.05$ & $8.6 \pm 0.85$ & III & $13.4 \pm 1.00$ & $10.8 \pm 0.75$ \\
\hline & $\Pi$ & $13.1 \pm 0.80$ & $9.4 \pm 0.77$ & IV & $13.5 \pm 0.24$ & $12.1 \pm 0.28$ \\
\hline \multirow{2}{*}{$\begin{array}{c}\text { Mean rate of eating } \\
\qquad(\mathrm{g} / 5 \mathrm{~min})\end{array}$} & 1 & $149 \pm 11.6$ & $191 \pm 19.1$ & III & $141 \pm 3.0$ & $229 \pm 15.9$ \\
\hline & II & $161 \pm 18.8$ & $238 \pm 24.3$ & IV & $153 \pm 3.5$ & $253 \pm 5.7$ \\
\hline
\end{tabular}

* Means are calculated from the values of the last 5 days of each treatment

Daily time spent eating with $24-\mathrm{hr}$ access was significantly longer than in a 4-hr and $2 \times 2-h r$ access $(P<.05)$, slightly higher values were obtained in $2 \times 2-h r$ access than in a 4 -hr access, but the difference was not significant. The similar trend was found on the daily intake. In one meal of 4 -hr the cows consumed $3 \mathrm{~kg}(1.8-4.5 \mathrm{~kg})$ less than in 24-hr access; this difference was significant $(\mathrm{P}<.05)$. The cows of Groups III and IV, having $2 \times 2-\mathrm{hr}$ access, consumed $2 \mathrm{~kg}(0.7-3.7 \mathrm{~kg})$ less than those with 24-hr access $(.10>\mathbf{P}>.05)$.

Mean rate of intake was significantly faster with $4-\mathrm{hr}$ than with $24-\mathrm{hr}$ access $(\mathrm{P}<.05)$; with $2 \times 2-\mathrm{hr}$ access the mean rate was faster than in $4-\mathrm{hr}$ access, but the difference was not significant.

Changes in eating pattern:

With $4-\mathrm{hr}$ and $2 \times 2-\mathrm{hr}$ access cows ate continuously until nearly the limit of the time of access to feed; with 24-hr access the cows ate during 4-17 periods each day, the mean time for individuals was $7.7 \pm 0.4$ (S.E.). The values on the first day, the second day and the subsequent days after changes in daily feeding time to $24-\mathrm{hr}$ access were $4.5,5.0$ and $7.3-8.5$ periods in Group II, and 5.5,6.8 and 6.0-7.5 periods in Group IV.

Cows had fewer periods of eating on the first and the second day in Group II $(\mathrm{P}<.05)$ and on the first day in Group IV (non-significant) than on the subsequent days.

No consistent trend in the response of eating pattern to adaptation to 24-hr access was found, except in the first eating period. The first eating period began when hay was offered; intakes during this period in 24-hr access in Groups II and IV are shown in Fig. 1. On the 
Feed intake of dairy cows

first day, and occasionally on the second day, after the change in treatment the length of the first eating period was significantly longer than those on the subsequent days. On three out of eight cows it decreased on the second day to the level of the subsequent days.

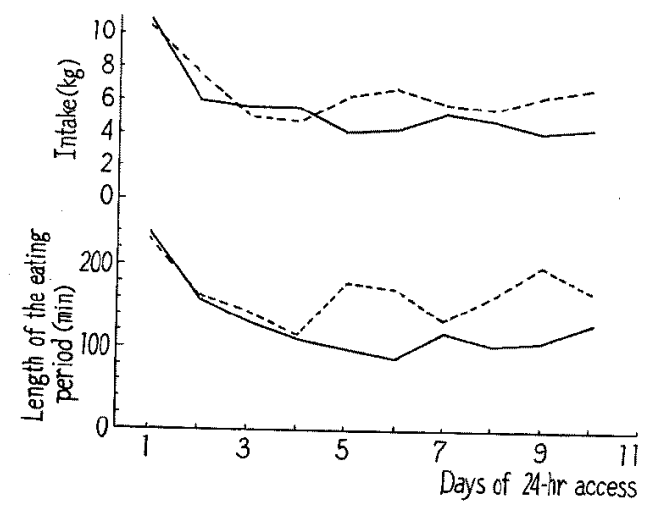

Fig. 1. Intake during the first eating period and the length of the period

(- Group II, --- Group IV)

changes in eating time:

Daily time spent eating in the four groups is given in Figs. 2 and 3 . On the day when daily feeding time changed to a 4-hr access (Group I) daily time spent eating was less than on the second day or subsequently; mean daily time spent eating was about a half that observed on the subsequent days. In Group III no such difference was observed in three cows out of four, although one cow spent less time (180 min) eating on the first day than subsequently. The trend observed in Group I was not shown in Groups II and IV, changed from restricted to 24-hr access to feed.

The cows receiving two meals of 2-hr daily ate almost throughout the time they had access to feed, but those receiving one meal of 4 -hr daily spent less time in eating than those receiving two meals.

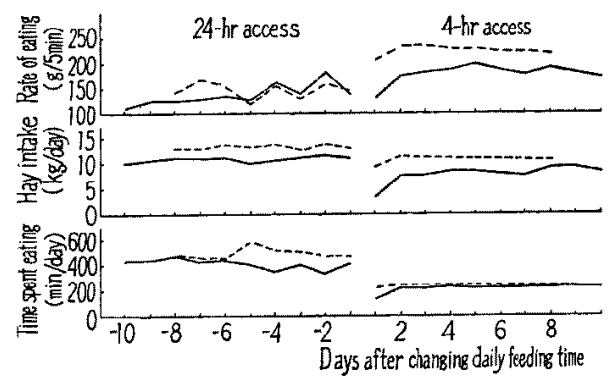

Fig. 2. Mean time spent eating, mean hay intake and mean rate of eating in Groups I and III

(- Group I, -.- Group III) 


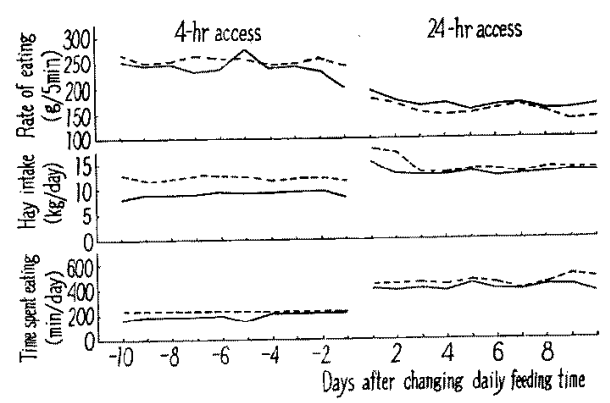

Fig. 3. Mean time spent eating, mean hay intake and mean rate of eating in Groups II and IV

$$
\text { (- Group II, --- Group IV) }
$$

Changes in daily intake and mean rate of eating:

Changes in the mean daily intakes and mean rate of eating in the four groups are also given in Figs. 2 and 3 . Intake on the first day after changing daily feeding time was less in Groups I and III $(P<.005$ for Group I, .20 $>P>.10$ for Group III), and more in Groups II and IV than on the subsequent days $(\mathrm{P}<.025)$.

Quicker mean rates of eating were shown with restricted access than with 24 -hr access. Mean rates with $24-\mathrm{hr}$ and a 4 -hr access (Groups I and II) were 155 and $215 \mathrm{~g} / 5 \mathrm{~min}$, while those with $24-\mathrm{hr}$ and $2 \times 2-\mathrm{hr}$ access (Groups III and IV) were 147 and $241 \mathrm{~g} / 5 \mathrm{~min}$, respectively. The cows ate faster with two 2 -hr periods than in one 4-hr period. Mean rates of intake on the first day after changing daily feeding time in Groups I, II and III, and on the first and the second day in Group IV were slower in Groups I and III, and faster in Groups II and IV than. on the subsequent days.

Although the difference between the mean rates of eating on the first day and on the subsequent days was less in Group III than in Group I, the mean rate during the first meal after changing daily feeding time to $2 \times 2-\mathrm{hr}$ was close to that on the first day in Group I, as shown. in Table 3. A similar trend was observed in the amount of food consumed.

Table 3. Mean rate of eating and the amount of intake in each meal in Group III

\begin{tabular}{cccccc}
\hline $\begin{array}{c}\text { Before or after } \\
\text { changing daily } \\
\text { feeding time }\end{array}$ & \multicolumn{2}{c}{ Rate of eating $(\mathrm{g} / 5 \mathrm{~min})$} & \multicolumn{2}{c}{ Amount of intake $(\mathrm{kg})$} \\
\cline { 2 - 5 } & Morning & Evening & Morning & Evening \\
\hline Before & \multicolumn{2}{c}{$141 \pm 5.9$} & & \multicolumn{2}{c}{$13.4 \pm 1.00$} \\
\hline 1st day & 155 & 256 & 3.3 & 6.2 \\
2nd day & 211 & 261 & 5.1 & 6.3 \\
3rd day & 224 & 250 & 5.4 & 6.0 \\
4th day & 218 & 245 & 5.2 & 5.9 \\
5th day & 204 & 256 & 4.9 & 6.2 \\
6th day & 212 & 237 & 5.1 & 5.7 \\
7th day & 225 & 221 & 5.4 & 5.3 \\
\hline S. E. of a day, & 17.8 & 15.7 & 0.47 & 0.38 \\
mean & & & & \\
\hline
\end{tabular}




\section{Discussion}

Effect of daily feeding time:

Daily time spent eating with 24-hr access was 361 to $513 \mathrm{~min}$, approximately twice as long as with 4-hr access daily (189 to $222 \mathrm{~min}$ ). Although the rate of eating increased markedly when access was restricted to 4-hr, the increase was insufficient to prevent a reduction in feed intake. This observation is in agreement with that of FrEer et $a l^{23}$ on the rate of eating, when daily time cows had access to hay was reduced from $24 \mathrm{hr}$ to $4 \frac{1 / 2}{2} \mathrm{hr}$.

In spite of eating time being similar to that observed with 4-hr access, two meals of 2-hr each permitted cows to consume larger amounts of hay and to eat more quickly than one meal of 4-hr. Reduction of the amount of digesta in the reticulo-rumen and the progress in metabolic turnover during the period of $8 \mathrm{hr}$ between the meals may have been implicated in this increased intake.

Eating behaviour in the course of adaptation:

On the day daily feeding time changed from $24-\mathrm{hr}$ to $4-\mathrm{hr}$, the eating pattern of the cows during the $4 \mathrm{hr}$ of access was the same as it had been with 24-hr access; this resulted in a similar rate of eating, shorter eating time and lower intake. On the second or the third day, however, those values settled down to the levels for the subsequent days (Groups I and III in Fig. 2). These facts suggest that most cows had learned to expect the limited time of access to feed by the early part of the second day and had by then adapted their eating behaviour to the new systern of feeding.

At the first meal, after a change in daily feeding time from $24-\mathrm{hr}$ to $2 \times 2-\mathrm{hr}$, cows ate as slowly as with 24-hr access, but intakes and the rates of eating at the second meal had attained the levels of the subsequent meals. These facts seem to show that adaptive behaviour to the change of the daily time of access to feed will occur as early as in the second meal, although the adaptation of cows has certain limitation in the rate of eating, and consequently in the daily intake.

The cows of Groups II and IV consumed more hay on the day the time of access to feed was changed from 4-hr to $24-\mathrm{hr}$ than on the subsequent days, whereas daily time of eating showed no distinct difference. Mean rates of eating during the first $2 \mathrm{hr}$ after offering hay for 4-hr, on the first day of $24-\mathrm{hr}$ access and on subsequent days were 256,298 and $216 \mathrm{~g} / 5 \mathrm{~min}$, respectively, but the differences were not significant. The fact that most cows ate faster on the first day of 24-hr access than on the other days suggests that the offer of a larger amount of hay probably stimulates temporarily the rate of eating.

Though there was no appreciable difference in the daily time spent in eating, by Groups II and IV, between the first day and subsequent days of 24-hr access, the characteristic patterns of eating behaviour were shown on several days after changing to 24 hr access. As shown in Fig. 1, the intake during the first eating period of a day and the length of the period were higher on the first day. In some of the cows it decreased for $2-4$ days and attained the levels of the subsequent days. It is reasonable to assume that several days should be allowed for adaptation of eating pattern to the change of time of access to feed. 


\section{Summary}

Time of eating and feed intake were recorded successively on 16 non-lactating dairy cows fed on mixed hay. The length of daily feeding time was changed from 24 -hr to 4-hr and vice vers $a$ and observations were made on the behaviour of the cows.

When daily feeding time was restricted to 4-hr the cows ate nearly all the time they had access to feed with a rapid rate of eating, but they could not prevent a reduction in feed intake compared to those with $24-\mathrm{hr}$ access. In two meals of $2-\mathrm{hr}$ the cows consumed more hay, with a quicker rate of eating, than in one meal of 4 -hr.

On the day access time changed from $24-\mathrm{hr}$ to 4 -hr intake was significantly less, and after changing from 4-hr to $24-\mathrm{hr}$ it was longer than on subsequent days; this was because the rate of eating did not change immediately. At the second meal, however, intake and the rate of eating nearly attained the levels at the subsequent meals. It was suggested that cows adapt in feeding behaviour to the change of daily feeding time in a short period; one or two days.

Acknowledgements

We wish to acknowledge gratefully the advice of Dr. C.C. BALCH during the writing of this paper and are also grateful to Mr. S. Aragane, Mr. M. Goto, Mr. T. Nakada and Mr. M. Sato. for experimental assistance.

\section{References}

1) Cohn, C. and D. Joseph (1960) Am. J. Clin. Nutr., 8, 682-690.

2) Freer, M., R.C. Campling and C.C. Balch (1962) Brit. J. Nutr., 16, 279-295.

3) Lepkovsky, S., A. Chari-Briton, R.M. Lemmon, R.C. Ostwald and M.K. Dimick (1960) Poultry Sci., 39, 385-389.

4) Siegel, H.S. and G.W. Wood (1964) Poultry Sci., 43, 406-410.

5) Suzuki, S., H. Fujita and Y. Shinde (1969) Anim. Prod., 11, 29-41.

6) Tepperman, J. and H.M. Tepperman (1958) Am. J. Physiol., 193, 55-64. 
給飼時間の変更が乳牛の乾草摄食速度と掑食量におよぼす影響

\author{
鈴木省三・新出陽三・左 久 \\ (帯庆蓄産大学)
}

1 日の給飼時間の变更に対して，乳牛がどのように対 応寸るかる知るため，16頭のホルスタイン種乾乳牛を 4 頭ずつ4群に分け，乾草単飼で20日間の撜食行動を 連続記録し，10日目に給飼時間を变更，その前後の摂食 量・時間・速度を比較检討した。

各群の前・後半の給飼时間は，それぞれ，第 I群不断 給飼乞 4 時間 1 回給飼，第II群 4 洔間 1 回給飼上不断給 飼，第而群不断給飼之2 時間 2 回給飼，第IV群 2 時間 2 回給飼と不断給飼とした. 乾草は少なくしも約 $10 \%$ を 食べ残す程度の量を，2 時間 2 回給与期には午前 6 時と 午後 4 時，他の期には午前8 時に実䮦用飼槽に入れて与 夫，飲料水および固型塧を别に常偨した，掑食行動の記 録注，飼槽内の給与乾草の重量変化要歪計・打点式記録 計にとらえる力法により，記録紙速度洁1時間 $150 \mathrm{~mm}$ とした，結果は次のと抬りであった。

(1) 1 日 4 時間給解の時は, ほとえど給飼時間 1 杯，速い速度て拱食したが，1日の提食量は不断給飼時
に及ばなふった４４持閒 1 回給飼よりを2洔間 2 回給飼 の方が，やや速く，より多く提俍した。

（2）不断給飼から4 時間給飼に切り替无た日には, 提食速度は不断給飼期と変わらず, 1 日の提食量は極度 に減少した， 2 時間 2 回給飼に切り替えた群では，朝の 給的司時には同様の現象が見られたが，夕刻の給飼時には 既に掑食速度が大きくなり，搑食量は朝の 2 倍にも達し t:.

（3）1日4時成給飼から，不断給飼に切り替えた日 には，朝の摂食速度は 4 時間給飼期に近く，1日の総掑 食時間は不断給飼期と変わりなかったが，撜食量は著し く多引った。

（4）給飼時間切智日のこれらの著明な傾闸は，2-3 日日から,それぞれ 4 時間給飼・不断給飼時の提食速

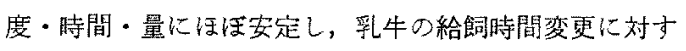
る順応はきわかて速いことが観察された。 